\title{
Farewell to Hegemony
}

\author{
Fyodor A. Lukyanov
}

\author{
Fyodor A. Lukyanov \\ Russia in Global Affairs \\ Editor-in-Chief; \\ National Research University-Higher School of Economics, Moscow, Russia \\ Faculty of World Economy and International Affairs \\ Research Professor \\ SPIN RSCI: 4139-3941 \\ ORCID: 0000-0003-1364-4094 \\ ResearcherID: N-3527-2016 \\ Scopus AuthorID: 24481505000 \\ E-mail: editor@globalaffairs.ru \\ Tel.: (+7) 4959807353 \\ Address: Office 112, 29 Malaya Ordynka Str., Moscow 115184, Russia \\ DOI: $10.31278 / 1810-6374-2021-19-3-5-8$
}

History develops surprisingly rhythmically sometimes, moving at a measured pace. We can count its milestones every ten years since the end of the 20th century: 1991-Operation Desert Storm and the collapse of the USSR; 2001-9/11attacks in the U.S.; 2011-Arab Spring, the almost ritual murder of al-Gaddafi; 2021the messy withdrawal of Americans from Afghanistan and the triumph of the Taliban. Of course, the world has seen other important events happening over these years, but we take only those that have ushered in qualitative changes in the world order.

Biden's speech on August 16, 2021, where he commented on the circumstances surrounding the completion of the U.S. mission in Afghanistan, and his statement on September 1 should be considered a turning point in U.S. foreign policy. "I know my decision will be criticized but I would rather take all that criticism than pass this decision on to another president," Biden said, implying that his three predecessors had failed to make the necessary step. He thus took a dig not only at Donald Trump (mentioning him by name), but also at George W. Bush, and even Barack Obama. According to Biden, the United States had never intended to engage in nation-building in Afghanistan, 
but addressed specific security tasks to destroy those responsible for the terrorist attacks on America, and these tasks were solved. As for nation-building, it is a complete lie, but it is noteworthy how eagerly Washington is now renouncing the postulates it considered pivotal twenty years ago.

The 2001 invasion of Afghanistan was an act of retaliation for the terrorist attacks in New York and Washington, but, above all, it was a landmark operation that signified the United States' readiness to forcefully transform the world in the "right" way. This course was chartered not by George W. Bush, and not even by Bill Clinton, but by the American president who proclaimed victory in the Cold War-George H.W. Bush. The first manifestation of the "new world order" was Operation Desert Storm in early 1991. The Soviet Union still existed at that time, and the intervention ended with the expulsion of Saddam Hussein from Kuwait, not with a regime change in Iraq, as some American politicians and the military had demanded. With the disintegration of the USSR, there were no external restraints left, and the United States entered the so-called "unipolar moment." It gave the United States the ability and the possibility to do whatever it saw fit on the world stage. In the military-political sense, this meant the absence of matching competitors. A series of trial balloons launched with varying degrees of success, like military actions in Haiti, Somalia, and Bosnia, culminated in the bombing of Yugoslavia. It resulted in the final disintegration of the unwanted state and the subsequent overthrow of the regime unacceptable to the West. This was done without ground invasion, even though it had been discussed in principle. Conceptually, the American post-Cold War era policy was formulated precisely in the 1990s. Its main author was Bill Clinton, known in his youth as a pacifist and draft dodger.

The $9 / 11$ attacks gave the U.S. a free hand in enforcing its "transformational approach" (Condoleezza Rice described it as the basis of the American policy) on a global scale. Creating a safe democratic world for Americans had actually become the main goal-the more democracies there are, the lower the risk for the United States. The toolkit of military-political instruments to be used for achieving this goal (from armed intervention to the promotion of approved forms of socio-political organization by means of color revolutions) was formed in the first half of the 2000s. But already by the middle of that decade, there had appeared the first signs indicating that this policy had its drawbacks, to say the least, and did not necessarily produce the expected results. 
The drawn-out campaign in Afghanistan, messy developments in Iraq, the growing "resistance of material" in the post-Soviet space, the fatal dysfunction of Palestine after the imposed democratic elections-all this should have raised awareness of what Biden hinted at in his speech on Afghanistan: the need for a radical change in policy. However, neither George W. Bush during his second term, nor Barack Obama, nor even rebellious Trump could do this. Practical correction began under Bush, Obama tried to begin a smooth departure from obligations without changing the narrative, and Trump sharply changed the rhetoric and disavowed the previous policies, but did not have time to complete the job.

The Kabul disaster in August 2021 could probably have been avoided if Washington had been more responsible and thoughtful in curtailing its presence in Afghanistan. But, apparently, it was too confident of itself and also hindered by the ideological and propaganda wrangles in the country. The perception of the United States as an unconditional global hegemon became so entrenched in the American establishment after the Cold War that a departure from it provoked fierce resistance, even though very many objectively understood that it was no longer possible to go on like this. In other words, the desire to camouflage diminishing ambitions and imitate their continuity, and the principled commitment to ideological foundations did not allow the U.S. to cut the burden in a controlled way. As a result, the whole world watched in astonishment as the situation snowballed into a crisis and fell into chaos, accompanied by accusations of betraying allies and ideals. The American global hegemony of the 1991-2021 edition was so impressive and probably unprecedented in scale that a mild and gradual departure from it was not possible. This event was to be marked by something no less historical and symbolic than the fall of the Berlin Wall or aircraft attacks on New York's twin towers. Footage capturing the escape from the Kabul airport and everything that accompanied it will go down in history as an epitome of the end of an era. In his speech, Biden basically announced that America would focus on itself and its problems to ensure its own security and fight strategic rivals (China and Russia), but it would no longer seek to change the world-it is what it is. This is a sobering moment after the euphoria of the late 20th century. Relapses are possible, but there is no return to the previous U.S. status.

The U.S. withdrawal from Afghanistan is "about ending an era of major military operations to remake other countries," Biden said, 
announcing the end of the airlift. The "America is back" slogan he repeated so many times during his presidential campaign means, as we can see, not a new comeback to the global arena, but a "return home." In this sense, Biden continues Trump's policy, no matter how strongly he dislikes him. This is also true of the "confrontation between the great powers" as the main point of global and American policies. This postulate is laid out in doctrinal documents adopted under Trump, but has not been revisited under Biden. Rhetorically, the present U.S. administration attaches ever-growing importance to the ideological component-the confrontation between democracy and autocracy. But this is done more for instrumental purposes in order to ease the formation of blocs and the structuring of world politics. After the Afghan embarrassment (to put it mildly) this part of the "Biden doctrine" pales into insignificance.

No matter what rhetoric accompanies real actions, the United States is switching to openly selfish policies geared exclusively to itself. Twenty years ago, staunch neoconservatives and neoliberals in Washington truly believed that the establishment of democracy around the world and the imposition of universal rules was in America's best interest. Hence the insane plans to build a "modern democratic state" in Afghanistan, now denied by Joe Biden. Now that the dreams have dissipated, only pure pragmatism is left, with rules being pushed aside. The era of "post-bipolarity," which, as we understand now, was not a period of creation, but deconstruction, contained some institutional inertia of the second half of the 20th century, probably the most ordered period in world political history. In general, the U.S. transition to a selfish policy is a positive shift, at least it is honest. Figments about the "torch of democracy," even (especially) if they are believed, only exacerbate chaos. But all of American counterparts in the international arena should not forget that the United States will now use all means available to achieve its goals, primarily domestic ones, because it is very important to it. Everyone else should be ready for this. 